\title{
Tourism planning: an integrated and sustainable development approach
}

\author{
Simin Tavallaee ${ }^{\mathrm{a}}$, Ali Asadi ${ }^{\mathrm{b}}$, Hamid Abya ${ }^{\mathrm{a}^{*}}$ and Mohsen Ebrahimi ${ }^{\mathrm{c}}$
}

\author{
${ }^{a}$ Department of Geography, University of Kharazmi, Tehran, Iran \\ ${ }^{b}$ Imam Hosein University, Tehran, Iran \\ ${ }^{c}$ Phd student, Department of Management, Tarbiat Modarres University, Tehran, Iran

\section{H R O N I C L E

$$
\text { A B S T R A C T }
$$

Article history:

Received June 10, 2014

Accepted 10 November 2014

Available online

November 142014

City development

SWOT

QSPM

IEA

Qom

Tourism industry

Shrine of Fatema Mce'sume

\section{Introduction}

Tourism has its effect on economic, cultural and political affairs (Simpson, 2001). Tourism creates job, stimulates economic investment, increases foreign travel demand, increases security in the country and makes it a reliable source of income for local people (Inskeep, 1991). Many countries receive more income from tourism than any other industries such as natural resources, etc. Tourism also plays an important role in encouraging investment in infrastructure, creating revenue for the state and its direct and indirect job involvement across the world (Heath \& Wall, 1991). The development of this industry in industrialized countries diversifies income and reduces the imbalance in the economy (Getz, 1983). In developing countries, it creates the opportunity for export, production and job creation. In addition, the benefits of tourism are not limited to economic interest but it helps us

*Corresponding author.

E-mail addresses: h_abya@yahoo.com (H. Abya)

C) 2014 Growing Science Ltd. All rights reserved. doi: $10.5267 / \mathrm{j} . \mathrm{ms} 1.2014 .11 .008$ 
introduce the culture of a country to other countries. Tourism characteristics of each location in influenced by the importance of validity, nature, role and function of a variety of religious, cultural, recreational, commercial and general attractions of its location (Allen, 1998). On the other hand, it has been influenced by the characteristics of the social, cultural (religious belief) and local residents and tourism economy.

The shrine of Fatema Mæ'sume (sister of Imām 'Al̄̄ ibn-Mūsā Riđā) is located in city of Qom considered by Shia Muslims to be the second most sacred city in Iran after Mashhad. Fatima Masumeh was the sister of the eighth Imam'Ali al-Rida and the daughter of the seventh Imam Musa al-Kadhim (Canby, 2009). According to Shia Islam believes, women are revered as saints if they are close relatives to one of the Twelver Imams. Fatima Masumeh is also honored as a saint, and her shrine in Qom is one of the most magnificent Shi'i shrines in Iran. Each year, thousands of Shi'i Muslims travel to city of Qom to honor Fatima Masumeh and ask her for blessings.
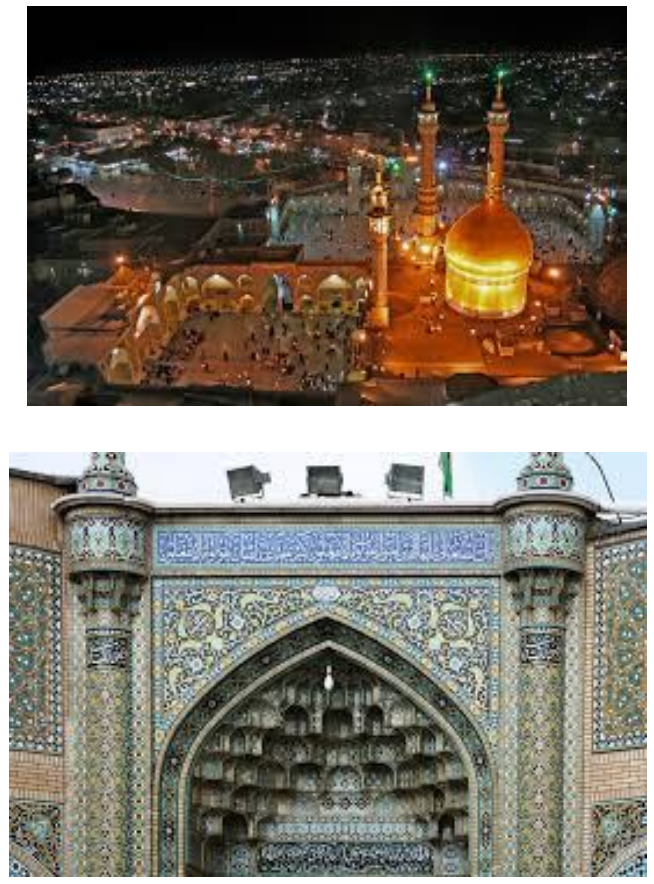
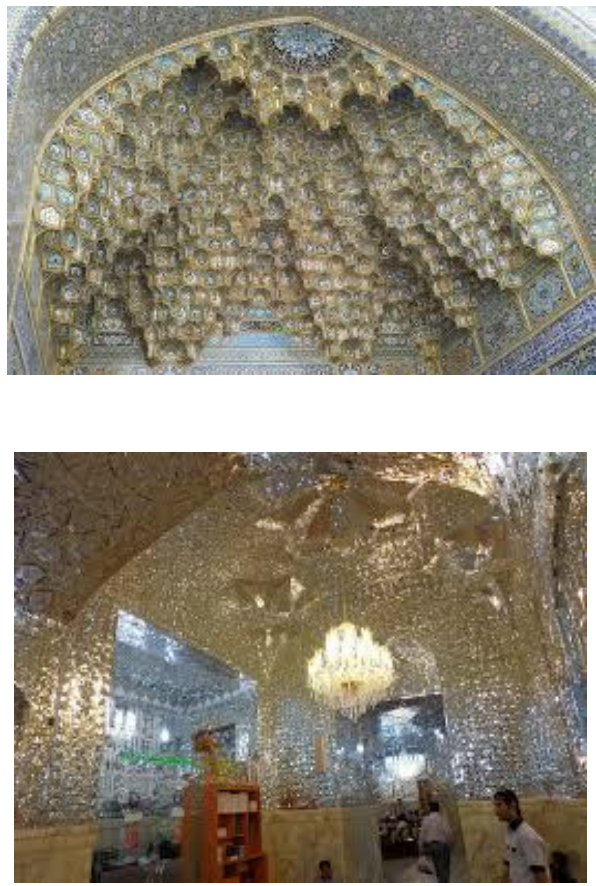

Fig. 1. The shrine of Fatema Mæ'sume

The mosque consists of a burial chamber, three courtyards and three large prayer halls, with an area of $38,000 \mathrm{~m} 2(410,000 \mathrm{sq} \mathrm{ft})$ (Jaffer, 2011). The history of city of Qom's goes back to the 7th century and it was associated with Shi'ism and set apart from the Sunni caliphate. Many Shi'i hadiths referred to Qom as a "place of refuge for believers", calling it a deeply religious place. After Fatima Masumeh's death in Qom and the construction of her Shrine, scholars started to gather in Qom and the city received its reputation for religious learning. Today, Qom is still named for its religious seminaries and organizations (Canby, 2009). Fatima Masumeh passed away in Qom in 201 A.H. as she travelled to join her brother, Imam Ali al-Rida in Khorasan. The caravan she travelled in was attacked in Saveh by enemies to the Shi'i's, and 23 of Fatima Masumeh's family and friends were killed (Jaffer, 2011). She was poisoned by a women from the enemies, fell ill, and requested to be taken to Qom, where she died. The style of Fatima Masumeh's Shrine has developed over many centuries. First, her tomb was covered with a bamboo canopy and later a dome was built above her tomb.

Though Shi'i theology officially states that the relatives of the Imams, or imamzadehs, hold a lower status compared with 12 Imams. In Iran, there are several burial places of the Imams' relatives. 
Imamzadehs are close to God and religiously pious because of their close relationships to 12 Imams. Shi'is usually travels on pilgrimages to shrines of imamzadehs, such as the Shrine of Fatima Masumeh in city of Qom, Iran. People look for cures to ailments, solutions to some problems, and forgiveness of sins at these sites. According to several hadiths, or teachings, from Shi'i Imams praising the veneration of Fatima Masumeh, and proclaiming that those who make a pilgrimage to her Shrine will "certainly be admitted to heaven" (Betteridge, 2002).

The Shrine is crowded every day of the year with Shi'i Muslim from all around the world. Some stay for only a few hours or days praying at the mosque and circumambulating her tomb. The economy of the city of Qom strongly depends on this pilgrimage for the tourism it brings. In turn, Qom has remained conservative and traditional to maintain a pious environment for pilgrims. Many miracles are believed to happen at this shrine, and they are documented in a special office within the shrine complex (Majd, 2008).

Tourism in city of Qom with numerous natural attractions, religious, cultural, and historical monuments may play essential role for development of Iran's economy. However, achieving these benefits would be possible and desirable when appropriate civil society and social infrastructure become available. However, before any planning is accomplished, there is a need to collect the necessary data. The city of Qom has various competitive advantages, which helps development of the city. In fact, the best utilization of resources in tourism may play essential role for development on national economy. Qom is the $8^{\text {th }}$ largest city in Iran, lies 125 kilometers $(78 \mathrm{mi}$ ) by road southwest of Tehran and it is the capital of Qom Province. According to 2011 census the population of the city was 1,074,036 (957,496 at the 2006 census, in 241,827 families), comprising 545,704 men and 528,332 women. It is located on the banks of the Qom River, enjoys a dry and warm climate with low annual rainfall due to remoteness from the sea and being located in the vicinity of desert.

\section{The proposed study}

The purpose of this study is to provide strategic assessment and optimization strategies for development of tourism industry to reach sustainable tourism development in city of Qom metropolis. The study uses three techniques namely; Quantitative Strategic Planning Matrix (QSPM), integrated environmental assessment (IEA) and strengths, weaknesses, opportunities and threats (SWOT) for the implementation of the study. The study first uses SWOT to categorize different factors, IEA is applied to determine internal as well as external factors and finally QSPM is applied to prioritize various factors.

\subsection{SWOT analysis}

A SWOT analysis is a structured planning technique implemented to evaluate the strengths, weaknesses, opportunities and threats involved in a project or in a business venture. A SWOT analysis can be also used for city development. SWOT involves specifying the objective of the business venture or project and determining the internal and external factors, which are favorable and unfavorable to achieve that objective. The following summarizes different perspectives of SWOT,

- Strengths: characteristics of the business, which give it an advantage over others,

- Weaknesses: characteristics that place the business at a disadvantage compared with others,

- Opportunities: elements the project could exploit to its advantage,

- Threats: elements in the environment, which could create trouble for the business.

Identification of SWOTs is essential because they can inform later steps in planning to achieve the objective. 


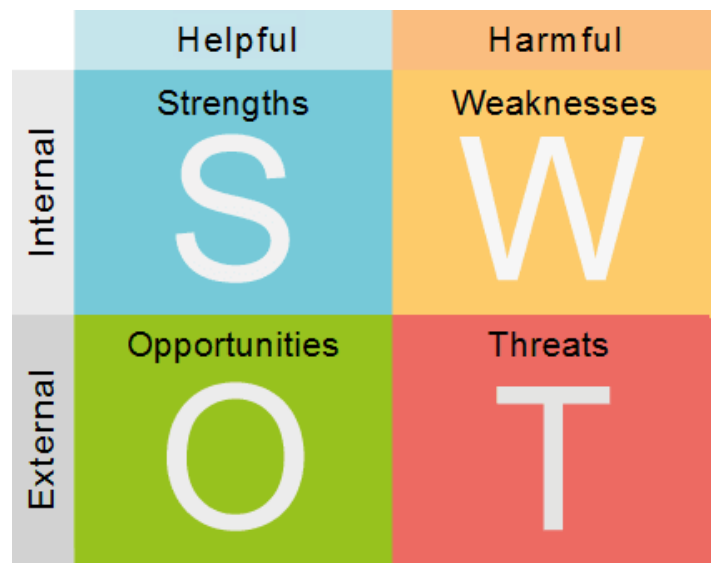

Fig. 2. The structure of SWOT

The analysis consists of two major items of external and internal factors. Table 1 demonstrates the summary of opportunities and threats associated with external factors.

\section{Table 1}

The summary of external factors

\begin{tabular}{|c|c|c|c|c|}
\hline & Description & Importance & Weight & Final \\
\hline \multirow{13}{*}{ 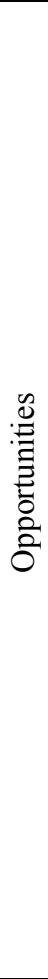 } & $\begin{array}{l}\text { Availability of exiting guaranteed domestic customers and steady increase of } \\
\text { demand for tourism }\end{array}$ & 0.07 & 3.6 & 0.25 \\
\hline & Compatibility of tourism functions with city development objectives & 0.062 & 3.0 & 0.18 \\
\hline & $\begin{array}{l}\text { Actual and potential tourism markets in neighboring Muslim countries and cultural } \\
\text { adaptation of the host society }\end{array}$ & 0.046 & 3.2 & 0.16 \\
\hline & $\begin{array}{l}\text { Urban and regional political and economic bargaining power of the holy city of } \\
\text { Qom as the second macro city }\end{array}$ & 0.05 & 3.25 & 0.16 \\
\hline & $\begin{array}{l}\text { Numerous national and international exhibitions and the opportunity to exploit the } \\
\text { potential of tourism business }\end{array}$ & 0.06 & 3.30 & 0.19 \\
\hline & $\begin{array}{l}\text { Willing to take advantage of health care and medicine for the people in the } \\
\text { neighboring countries and the countries of the southern border city of Qom located } \\
\text { in the region of Persian Gulf }\end{array}$ & 0.05 & 3.0 & 0.17 \\
\hline & $\begin{array}{l}\text { Introducing the city of Qom as the second religious metropolis city with various } \\
\text { cultural, historical and natural capacities such as Persian architecture, Islamic, } \\
\text { Desert, Salt Lake, etc. }\end{array}$ & 0.055 & 3.0 & 0.16 \\
\hline & Importance of tourism, domestic tourism, especially among politicians & 0.044 & 3.0 & 0.13 \\
\hline & $\begin{array}{l}\text { Proximity to tourist destinations and tourism hub exposure toward different Iranian } \\
\text { cities such as Tehran, Isfahan, Shiraz and Hamedan as well as access to the } \\
\text { national rail transportation system }\end{array}$ & 0.064 & 3.06 & 0.20 \\
\hline & $\begin{array}{l}\text { The positive attitude of the authorities in the field of cultural heritage tourism } \\
\text { development }\end{array}$ & 0.064 & 3.06 & 0.20 \\
\hline & $\begin{array}{l}\text { Tourists' feel of security and safety as well as hospitality of the people living in } \\
\text { the province. }\end{array}$ & 0.044 & 3.00 & 0.13 \\
\hline & $\begin{array}{l}\text { Existence of rules and regulations to facilitate the development of tourism } \\
\text { activities }\end{array}$ & 0.054 & 1.46 & 0.07 \\
\hline & Introducing the reputation of religious, cultural and historic city of Qom & 0.050 & 1.50 & 0.07 \\
\hline \multirow{6}{*}{ 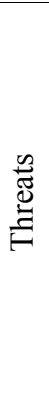 } & Reduced access of local people to social services and welfare & 0.046 & 1.56 & 0.07 \\
\hline & $\begin{array}{l}\text { The migration of the people from the old and the central part of Qom to other parts } \\
\text { of the city and depletion of authentic cultural and social context }\end{array}$ & 0.045 & 1.40 & 0.06 \\
\hline & $\begin{array}{l}\text { Tourism monoculture, despite having commercial potential of tourism } \\
\text { development, management, ecotourism and recreation }\end{array}$ & 0.066 & 1.60 & 0.1 \\
\hline & $\begin{array}{l}\text { Multiple systems of management and planning of the tourism sector and the lack } \\
\text { of an integrated management system for tourism management. Interaction of } \\
\text { various governmental organizations in the tourism sector }\end{array}$ & 0.036 & 1.30 & 0.04 \\
\hline & Evident dissatisfaction domestic tourists and sensitivity of foreign tourists & 0.049 & 1.55 & 0.08 \\
\hline & $\begin{array}{l}\text { Increasing pollution and environmental degradation in urban space and the social, } \\
\text { physical and functional }\end{array}$ & 0.045 & 1.50 & 0.07 \\
\hline
\end{tabular}


Table 2

The summary of internal factors

\begin{tabular}{lccc}
\hline Description & Importance & Weight & Final \\
\hline $\begin{array}{l}\text { Holy Shrine Masoumeh and the holy mosque Zaman (Jamkaran) and } \\
\text { 444 shrine }\end{array}$ & 1.01 & 3.63 & 0.38 \\
\hline $\begin{array}{l}\text { Vicinity to two major cities of Tehran and Esfahan } \\
\text { Tourism infrastructure development }\end{array}$ & 0.106 & 3.46 & 0.36 \\
$\begin{array}{l}\text { Existence of special and important tourism resources at the national } \\
\text { level and varied cultural and natural historical monuments }\end{array}$ & 0.09 & 3.42 & 0.31 \\
\hline Hinterland country having the capacity to develop eco-tourism & 0.095 & 0.31 \\
\hline $\begin{array}{l}\text { Low capacity for urban management in response to a doubling of the } \\
\text { volume of tourism demand, especially during peak season (lack of } \\
\text { resources, lack of personnel, etc.) }\end{array}$ & 0.092 & 3.45 & 0.34 \\
\hline $\begin{array}{l}\text { The lack of accurate and timely data and information from Qom tourism } \\
\text { sector, particularly in demand }\end{array}$ & 0.066 & 1.26 & 0.11 \\
\hline $\begin{array}{l}\text { Low capacity in the management and planning of tourism, tourism } \\
\text { management and planning services to tourists } \\
\text { The lack of a comprehensive strategic plan for tourism development }\end{array}$ & 0.085 & 1.59 & 0.10 \\
$\begin{array}{l}\text { The low amount of time tourists spend in Qom religious and lack of } \\
\text { diversity in services, poor performance of tourism facilities and services }\end{array}$ & 0.066 & 1.43 & 0.09 \\
$\begin{array}{l}\text { Weak monitoring for the performance measurement of the service } \\
\text { provider, shortage of shopping centers and other tourism services, poor } \\
\text { quality of old dining, entertainment and recreation }\end{array}$ & 0.069 & 1.68 & 0.060 \\
$\begin{array}{l}\text { Poor performance of travel agencies and tour organizer, weakness of the } \\
\text { public transport and urban traffic }\end{array}$ & 0.082 & 1.27 & 0.087 \\
\hline
\end{tabular}

Based on the results of Table 1 and Table 2, we may summarize the results in Fig. 1 as follows,

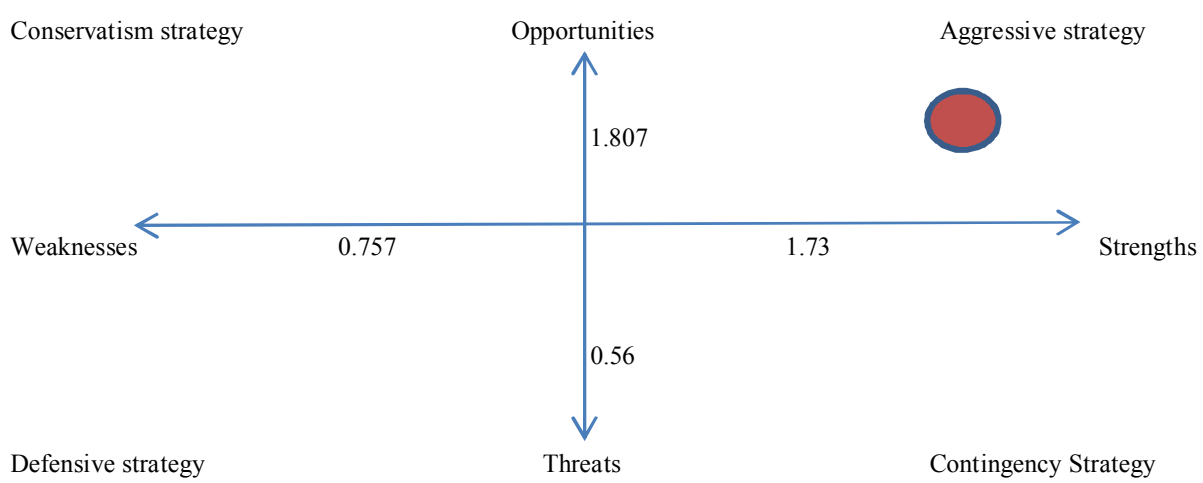

Fig. 1. The summary of SWOT analysis

According to the results of Fig. 1, the best strategy is to choose aggressive strategy. According to the approved SO strategies appropriate for the purposes of research and given the set of weaknesses and opportunities, in line with the sustainable development of the tourism metropolis of Qom, SO strategies to plan include: realization of the strategy of integrated management of urban tourism council through the entire city of Qom, with the aim of coordinating and clarifying goals, policies and actions of the executive in relation to both the tourism sector and tourism planning and management in the metropolitan city of Qom, strategic planning based on cultural heritage, handicrafts and tourism, following clear city development document, etc. 


\section{2. $Q S P M$}

In this section, we have performed an intensive brain storming among decision makers and used Quantitative Strategic Planning Matrix (QSPM) to rank different factors. Table 3 demonstrates the summary of our findings.

\section{Table 3}

The summary of the QSPM investigation

Strategic internal and external factors affecting the sustainable development of tourism in the city of Qom

\begin{tabular}{|c|c|c|c|c|c|}
\hline$\beta$ & $\begin{array}{c}\text { Integrated } \\
\text { Management } \\
\text { of Tourism }\end{array}$ & $\begin{array}{c}\text { Strategic } \\
\text { behavior of } \\
\text { Cultural } \\
\text { Heritage }\end{array}$ & $\begin{array}{c}\text { Support from } \\
\text { national and } \\
\text { international } \\
\text { organizations }\end{array}$ & $\begin{array}{c}\text { Attracting } \\
\text { domestic } \\
\text { and foreign } \\
\text { investment }\end{array}$ & $\begin{array}{c}\text { Organizing } \\
\text { old part of } \\
\text { city }\end{array}$ \\
\hline
\end{tabular}

\begin{tabular}{|c|c|c|c|c|c|c|}
\hline $\begin{array}{l}\text { Availability of exiting guaranteed domestic customers and } \\
\text { steady increase of demand for tourism }\end{array}$ & 0.07 & 1 & 1 & 1 & 1 & 0.75 \\
\hline $\begin{array}{l}\text { Compatibility of tourism functions with city development } \\
\text { objectives as well as country's goals }\end{array}$ & 0.062 & 0.2 & 0.2 & 0.2 & 0.15 & 0.15 \\
\hline $\begin{array}{l}\text { Actual and potential tourism markets in neighboring } \\
\text { Muslim countries and cultural adaptation of the host } \\
\text { society }\end{array}$ & 0.046 & 0.2 & 0.2 & 0.2 & 0.2 & 0.2 \\
\hline $\begin{array}{l}\text { Urban and regional political and economic bargaining } \\
\text { power of the holy city of Qom as the second macro city }\end{array}$ & 0.05 & 0.12 & 0.06 & 0.09 & 0.03 & 0.0 \\
\hline $\begin{array}{l}\text { Numerous national and international exhibitions and the } \\
\text { opportunity to exploit the potential of tourism business }\end{array}$ & 0.06 & 0.09 & 0.12 & 0.12 & 0.12 & 0.09 \\
\hline $\begin{array}{l}\text { Willing to take advantage of health care and medicine for } \\
\text { the people in the neighboring countries and the countries } \\
\text { of the southern border city of Qom located in the region } \\
\text { of Persian Gulf }\end{array}$ & 0.055 & 0.09 & 0 & 0.12 & 0.12 & 0.06 \\
\hline $\begin{array}{l}\text { Introducing the city of Qom as the second religious } \\
\text { metropolis city with various cultural, historical and } \\
\text { natural capacities such as Persian architecture, Islamic, } \\
\text { Desert, Salt Lake, etc. }\end{array}$ & 0.044 & 0.06 & 0.045 & 0.06 & 0.06 & 0.06 \\
\hline $\begin{array}{l}\text { Importance of tourism, domestic tourism, especially } \\
\text { among politicians }\end{array}$ & 0.064 & 0.04 & 0.04 & 0.03 & 0.04 & 0 \\
\hline $\begin{array}{l}\text { The low amount of time tourists spend in Qom religious } \\
\text { and lack of diversity in services, poor performance of } \\
\text { tourism facilities and services }\end{array}$ & 0.064 & 0.015 & 0.015 & 0 & 0.02 & 0.015 \\
\hline $\begin{array}{l}\text { The lack of a comprehensive strategic plan for tourism } \\
\text { development }\end{array}$ & 0.044 & 1 & 0.71 & 1 & 0 & 0 \\
\hline Increase rate of tourists' complaints & 0.054 & 0.4 & 0.3 & 0.2 & 0.3 & 0.4 \\
\hline Increase rate of pollution and low quality of life & 0.05 & 0.32 & 0 & 0.04 & 0 & 0.32 \\
\hline $\begin{array}{l}\text { Reduced access of local people to social services and } \\
\text { welfare }\end{array}$ & 0.050 & 0.32 & 0 & 0.04 & 0 & 0.16 \\
\hline $\begin{array}{l}\text { The migration of the people from the old and the central } \\
\text { part of Qom to other parts of the city and depletion of } \\
\text { authentic cultural and social context }\end{array}$ & 0.049 & 0.08 & 0 & 0.04 & 0 & 0.12 \\
\hline Tourism as one type product & 0.045 & 0.06 & 0.08 & 0.06 & 0.08 & 0 \\
\hline $\begin{array}{l}\text { Holy Shrine Fatima-Al-Masumeh and the holy mosque } \\
\text { Zaman (Jamkaran) and } 444 \text { shrine }\end{array}$ & 0.046 & 1 & 0.75 & 0 & 1 & 1 \\
\hline Vicinity to two major cities of Tehran and Esfahan & 0.045 & 0.2 & 0.15 & 0 & 0.2 & 0.15 \\
\hline Tourism infrastructure development & 0.066 & 0.09 & 0.12 & 0.09 & 0.12 & 0.12 \\
\hline $\begin{array}{l}\text { Existence of special and important tourism resources at } \\
\text { the national level and varied cultural and natural historical } \\
\text { monuments }\end{array}$ & 1.01 & 0.09 & 0.12 & 0.12 & 0.12 & 0.12 \\
\hline $\begin{array}{l}\text { Hinterland country having the capacity to develop eco- } \\
\text { tourism }\end{array}$ & 0.106 & 0.09 & 0.08 & 0.04 & 0.06 & 0 \\
\hline $\begin{array}{l}\text { Low capacity for urban management in response to a } \\
\text { doubling of the volume of tourism demand, especially } \\
\text { during peak season (lack of resources, lack of personnel, } \\
\text { etc.) }\end{array}$ & 0.102 & 0.40 & 0.10 & 0.40 & 0.40 & 0.40 \\
\hline $\begin{array}{l}\text { The lack of accurate and timely data and information } \\
\text { from Qom tourism sector, particularly in demand }\end{array}$ & 0.095 & 0.20 & 0.20 & 0 & 0 & 0 \\
\hline $\begin{array}{l}\text { The low amount of time tourists spend in Qom religious } \\
\text { and lack of diversity in services, poor performance of } \\
\text { tourism facilities and services }\end{array}$ & 0.095 & 0.32 & 0.32 & 0.24 & 0 & 0 \\
\hline Poor performance of accommodations & 0.066 & 0.32 & 0.32 & 0.24 & 0.32 & 0.16 \\
\hline Poor performance of entertainment & 0.085 & 0.12 & 0.12 & 0.09 & 0.12 & 0.06 \\
\hline Poor performance of transportation facilities & 0.066 & 0.15 & 0.05 & 0.2 & 0.15 & 0.2 \\
\hline Low quality of old part of the city & 0.040 & 0.15 & 0.05 & 0.15 & 0.1 & 0.2 \\
\hline Lack of information about different occasions & 0.069 & 0.09 & 0.12 & 0.12 & 0 & 0 \\
\hline
\end{tabular}




\section{Discussion and conclusion}

The major findings of this study suggest that the role of tourism in relationship with external factors is desirable and there are more opportunities than threats. However, in terms of internal factors, the city is not in desirable situation. Having a guaranteed market growth through increasing domestic tourism, consistency of the religious believes with governmental rule and regulations, existence of big market of the Muslims who live in neighboring countries and vicinity to capital city of the country are among the most important factors influencing tourism in holy city of Qom. However, the city suffers from different weaknesses such as low capacity for urban management, especially during peak season, lack of accurate and timely data and information, low capacity in the management and planning of tourism. The city also suffers from tourism management and planning services to tourists. It does not have a comprehensive strategic plan for tourism development. There is low amount of time tourists spend in Qom religious, which makes it difficult to provide good services for them. Moreover, lack of diversity in services, poor performance of tourism facilities and services are among other issues, which must be resolved to improve tourism industry in this city. Weak monitoring for the performance measurement of the service provider, shortage of shopping centers and other tourism services, poor quality of old dining, entertainment and recreation and Poor performance of travel agencies and tour organizer, weakness of the public transport and urban traffic are among other issues, which must be handled, properly.

It is important to have legal infrastructure to support the strategy of national and international status of the country's second largest religious metropolis. It seems that the economy of the city must be integrated with national economy to absorb more financial support from different sources. The results of this study are consistent with findings reported by Ebrahimzadeh et al. (2011) and Freeman (1992).

\section{Acknowledgement}

The authors would like to thank the anonymous referees for constructive comments on earlier version of this paper.

\section{References}

Allen, L. R., Long, P. T., Perdue, R. R., \& Kieselbach, S. (1988). The impact of tourism development on residents' perceptions of community life. Journal of travel research, 27(1), 16-21.

Betteridge, A. H. (2002). Muslim Women and Shrines in Shiraz. In Donna Lee Bowen and Evelyn A. Early. Everyday Life in the Muslim Middle East, $2^{\text {nd }}$ ed.). Bloomington: Indiana University Press. pp. 276-289.

Canby, S. R. (2009). Shah 'Abbas: The Remaking of Iran. London: The British Museum Press.

Ebrahimzadeh, I., Kazamizd, S., \& Eskandari, S. M. (2011). Strategic planning for tourism development, emphasizing on religious tourism (case study: Qom City). Human Geography Research Quarterly, 76(2), 19-21.

Freeman, E. H. (1992). A knowledge-based approach to strategic planning. InLogic Programming in Action (pp. 109-117). Springer Berlin Heidelberg.

Getz, D. (1983). Capacity to absorb tourism: Concepts and implications for strategic planning. Annals of Tourism Research, 10(2), 239-263.

Heath, E., \& Wall, G. (1991). Marketing tourism destinations: a strategic planning approach. John Wiley \& Sons, Inc.

Inskeep, E. (1991). Tourism planning: an integrated and sustainable development approach. Van Nostrand Reinhold.

Jaffer, M. (2011). Lady Fatima Masuma (a) of Qum, Qum: Islamic Seminary for Women. 
Majd, H. (2008). The Ayyatolah Begs to Differ: The Paradox of Modern Iran. New York: First Anchor Books.

Simpson, K. (2001). Strategic planning and community involvement as contributors to sustainable tourism development. Current Issues in Tourism,4(1), 3-41. 